\title{
Profil Sikap Mencari Bantuan Layanan Psikologis pada Mahasiswa
}

\section{The Profile of Psychological Help-Seeking Attitude on Students}

\author{
Nurfadilah, ${ }^{1}$ Anisa Rahmadani, ${ }^{2}$ dan Bahrul Ulum ${ }^{3}$ \\ 'novanurfadilah@uai.ac.id \\ Universitas Al Azhar Indonesia \\ Komplek Masjid Agung Al Azhar, Jl. Sisingamangaraja, Jakarta 12110 \\ zanisa.rahmadani@uai.ac.id \\ Universitas Al Azhar Indonesia \\ Komplek Masjid Agung Al Azhar, Jl. Sisingamangaraja, Jakarta 12110 \\ 33bahrululum@uai.ac.id \\ Universitas Al Azhar Indonesia \\ Komplek Masjid Agung Al Azhar, Jl. Sisingamangaraja, Jakarta 12110
}

Naskah diterima: 1 Februari 2021 | Naskah direvisi: 19 Mei 2021 | Naskah diterbitkan: 30 Juni 2021

\begin{abstract}
The results of a survey by the Indonesian Psychology Student Association (ILMPI) show that students still do not understand the meaning of mental health services. Meanwhile, the results of the 2018 Basic Health Research stated that handling mental health is as important as physical health. Therefore, it is necessary to conduct research to get a picture of the attitudes of students in seeking psychological assistance in colleges. This mixed methods research was conducted at the University of Al Azhar Indonesia (UAl). Quantitative data was collected using a questionnaire on the attitude of seeking professional psychological assistance to 180 students, while the qualitative data were obtained using semi-open interviews with 12 students via telephone. The results showed that the students' attitudes tended to be neutral in seeking psychological help; students are even less familiar with the existence of psychological services and have a negative stigma against psychological services, and the psychological service campaign that has been carried out is ineffective. In order to create students who are healthy physically and mentally, therefore, this article suggests some points. First, as mandated by Law of the Republic of Indonesia Number 18 of 2014 concerning Mental Health, derivative regulations must be made at the level of ministerial regulation which mandates that universities should develop a strategy for the implementation of sustainable, implementative, comprehensive, and integrated youth psychological service units in universities. Second, Commission X DPR RI should oversee the process of forming these derivative regulations and supervise their implementation.
\end{abstract}

Keywords: college student attitudes; mental health; psychological services; seeking help profile

Abstrak: Hasil survei Ikatan Lembaga Mahasiswa Psikologi Indonesia (ILMPI) menunjukkan bahwa mayoritas mahasiswa masih tidak memahami maksud dari layanan kesehatan mental. Sementara hasil Riset Kesehatan Dasar tahun 2018 menyatakan bahwa penanganan kesehatan mental sama pentingnya dengan kesehatan fisik. Oleh karena itu, perlu dilakukan penelitian untuk mendapatkan gambaran tentang 
sikap mahasiswa dalam mencari bantuan psikologis pada perguruan tinggi. Penelitian mixed method ini dilakukan di Universitas Al Azhar Indonesia (UAI). Pengumpulan data kuantitatif dilakukan dengan menggunakan kuesioner Attitude Toward Seeking Professional Psychological Help terhadap 180 orang mahasiswa, sedangkan data kualitatif diperoleh menggunakan wawancara dengan format semi terbuka terhadap 12 orang mahasiswa via telepon. Hasil penelitian menunjukkan bahwa sikap mahasiswa cenderung netral dalam mencari bantuan psikologis; mahasiswa bahkan kurang familiar dengan keberadaan layanan psikologis, dan memiliki stigma negatif terhadap layanan psikologis; dan belum efektifnya kampanye layanan psikologis yang telah dilakukan. Demi tercapainya mahasiswa yang sehat fisik dan mental maka artikel ini menyarankan beberapa hal. Pertama, amanat Undang-Undang Republik Indonesia Nomor 18 tahun 2014 tentang Kesehatan Jiwa harus dibuatkan peraturan turunan pada tingkat penyelenggaraan universitas melalui peraturan menteri yang menangani pendidikan tinggi, yang di dalamnya mengamanatkan agar universitas menyusun strategi penyelenggaraan unit layanan psikologis remaja yang berkesinambungan, implementatif, komprehensif, dan terintegrasi dengan sumber-sumber dukungan yang dimiliki oleh perguruan tinggi. Kedua, Komisi X DPR RI sebaiknya mengawal proses pembentukan aturan turunan tersebut dan mengawasi pelaksanaannya.

Kata Kunci: kesehatan mental; layanan psikologis; profil mencari bantuan; sikap mahasiswa

\section{Pendahuluan}

World Health Organization (WHO) telah berkomitmen untuk mempromosikan kesehatan mental dan kesejahteraan sebagai bagian dari Tujuan Pembangunan Berkelanjutan, yang dikenal dengan Sustainable Development Goals atau SDGs (WHO, 2020). Kesehatan mental dan kesejahteraan ini termasuk ke dalam pilar pembangunan sosial, yang diharapkan dapat tercapai pada tahun 2030. Lebih lanjut dikatakan bahwa kesehatan mental mempunyai persentase yang cukup besar dari total beban penyakit global selama masa remaja, dan bunuh diri menjadi salah satu dari tiga penyebab utama kematian di kalangan remaja akhir (WHO, 2020). Sayangnya, remaja yang teridentifikasi memiliki gangguan kesehatan mental, sering kali rentan terhadap pengucilan sosial, diskriminasi, stigma (memengaruhi kesiapannya untuk mencari bantuan), kesulitan mengakses pendidikan, menampilkan perilaku berisiko tinggi, mengalami gangguan kesehatan fisik yang buruk dan melakukan tindak kekerasan (WHO, 2020).

Hal ini menunjukkan bahwa kesehatan mental sama pentingnya dengan kese- hatan fisik dan perlu penanganan serius, khususnya pada remaja, mulai dari langkah preventif, kuratif hingga promotif. Data dari hasil Riset Kesehatan Dasar (Riskesdas) tahun 2013-2018 (Kementerian Kesehatan Republik Indonesia, 2018) juga mendukung perlunya penanganan serius kesehatan mental pada remaja yang berusia lebih dari 15 tahun. Bagan 1 yang disadur dari hasil Riskesdas merangkum tren prevalensi gangguan mental pada penduduk yang berumur lebih dari lima belas tahun pada remaja.

Bagan 1 menunjukkan bahwa prevalensi gangguan mental emosional pada remaja yang berumur lebih dari 15 tahun mengalami peningkatan sebesar 6 persen jika dibandingkan dengan tahun 2013. Meningkatnya prevalensi gangguan mental dan emosional pada usia tersebut menunjukkan bahwa perlu adanya upaya penanganan serius kesehatan mental yang dapat dimulai dari institusi pendidikan yang sedang ditempuhnya.

Salah satu masa yang paling menantang bagi remaja adalah masa perkuliahan. Masa perkuliahan dianggap waktu yang ideal untuk pertumbuhan pribadi dan mempersiapkan masa depan. Fish- 


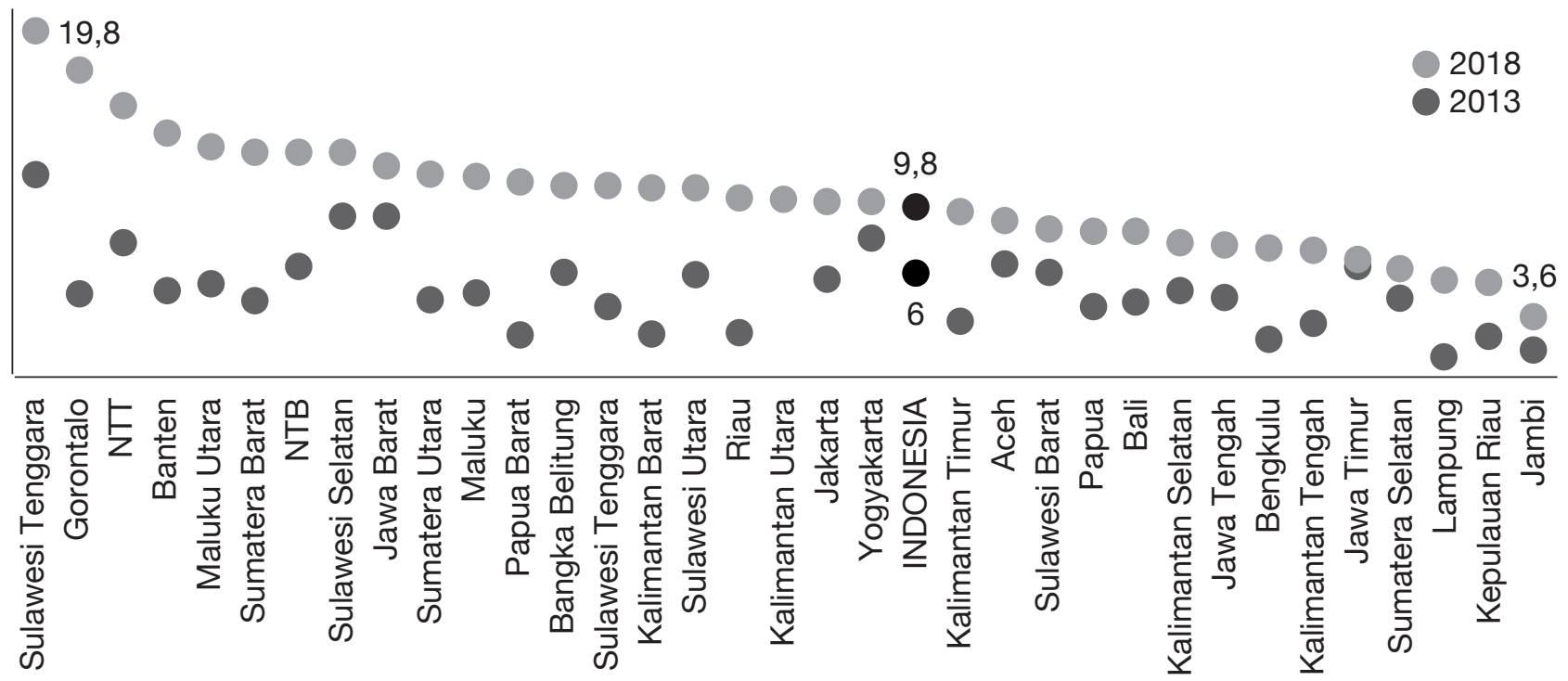

Bagan 1.

Prevalensi Gangguan Mental terhadap Penduduk yang Berumur $>15$ Tahun

Sumber: Kementerian Kesehatan (2018: 68)

er dan Noble (1960: 1) menyebut 'college education as personal development', karena di masa kuliah individu dihadapkan pada tiga keputusan yang paling penting dalam hidup, yakni pilihan pekerjaan, pilihan pasangan hidup, dan pilihan cara hidup. Meski begitu, banyak isu yang mengiringi keberhasilan mahasiswa dalam mengenyam pendidikan tingginya. Transisi psikologis dari remaja menuju dewasa awal, kehidupan kampus seperti perubahan budaya akademik dan institusi, serta besarnya tuntutan untuk mampu beradaptasi tidak jarang menimbulkan beban psikologis bagi mahasiswa (Krishnan \& Sequira, 2012).

Prevalensi global dan nasional menunjukkan adanya isu kesehatan mental di tataran perguruan tinggi yang perlu mendapat perhatian. Upaya pemberian dukungan psikologis kepada mahasiswa sebetulnya telah berkembang dan diterapkan oleh perguruan tinggi di dunia pada tahun 1960-an dan 1970-an. Pemberian bantuan psikologis menjadi bagian dari sistem pendidikan dengan istilah Counseling and Psychological Service (CAPS) yang terintegrasi dengan pusat kesehatan di kampus atau menjadi layanan konseling tersendiri sehingga berperan sebagai salah satu tempat pertama yang didatangi mahasiswa ketika mencari bantuan (Danzman, 2019).

Kesehatan jiwa di Indonesia, mendapat perhatian yang baik dari pemerintah yang ditunjukkan dengan adanya UndangUndang Republik Indonesia Nomor 18 Tahun 2014 tentang Kesehatan Jiwa dan Permen Ristekdikti Nomor 46 Tahun 2017 tentang Pendidikan Khusus dan Pendidikan Layanan Khusus di Perguruan Tinggi. Regulasi tersebut menunjukkan komitmen pemerintah untuk menjamin kesehatan jiwa masyarakat, termasuk mahasiswa, melalui upaya-upaya preventif, kuratif, maupun promotif (ILMPI, 2020). Kebijakan tersebut diperkuat dengan Permendiknas Nomor 27 Tahun 2008 tentang Standar Kualifikasi Akademik dan Kompetensi Konselor yang menyatakan bahwa satuan pendidikan yang mempekerjakan konselor wajib menerapkan standar kualifikasi akademik dan kompetensi konselor.

Sayangnya, fakta yang ditemukan oleh survei Ikatan Lembaga Mahasiswa Psikologi pada tahun 2020 menunjukkan bahwa mayoritas mahasiswa masih tidak memahami tentang layanan kesehatan mental yang berada di perguruan tinggi. Selain itu, survei tersebut juga menemu- 
kan bahwa kesadaran terkait kesehatan mental dan informasi yang memadai terhadap akses fasilitas kesehatan mental yang dimiliki kampus masih tergolong rendah (ILMPI, 2020). Lebih lanjut penelitian yang dilakukan oleh Rasyida (2019), mengungkap bahwa terdapat tiga faktor utama yang membuat mahasiswa enggan untuk mencari bantuan psikologis pada penyedia layanan kesehatan mental profesional (bantuan formal) di universitas, yaitu: (1) mahasiswa tidak tahu mana layanan konseling yang baik, (2) mahasiswa memiliki keluarga atau teman yang dapat menolong, dan (3) mahasiswa merasa bahwa masalahnya selama ini tergolong masih kurang serius.

Pada sisi lain, diketahui bahwa mahasiswa, yang berada pada fase remaja dan dewasa awal cenderung mencari bantuan informal dari teman dan keluarga, sebelum mencari bantuan formal kepada profesional ketika sedang berada dalam masalah psikologis (Griffiths, Crisp, Barney, \& Reid, 2011). Rendahnya keinginan untuk mencari bantuan profesional akan berdampak pada tingkat stres yang semakin tinggi dan hasil akademik yang buruk (Pedrelli, Nyer, Yeung, Zulauf, \& Wilens, 2015: 503). Penelitian yang dilakukan Vidourek, King, Nabors, dan Merianos (2014: 1010) juga menemukan bahwa tidak tertanganinya isu kesehatan mental serta tanpa adanya penanganan dari ahli yang tepat akan membuat mahasiswa yang mengalami gangguan kesehatan mental berisiko tinggi untuk tidak menyelesaikan studinya. Halangan untuk mencari bantuan psikologis tersebut, menurut Vidourek et al. (2014: 1010) berasal dari sikap negatif yang dimilikinya atau yang diterimanya dari orang lain. Individu dengan permasalahan mental kerap mendapat atribut negatif, misalnya lemah dan tidak kompeten karena tidak mampu menjaga dirinya sendiri. Senada dengan pendapat tersebut, Al-Darmaki (2011: 40) menyatakan bahwa sikap negatif juga ditemukan sebagai faktor utama yang berkontribusi terhadap keputusan mahasiswa untuk mencari bantuan konseling atau tidak.

Studi kualitatif lain yang dilakukan terhadap 47 mahasiswa tingkat awal yang dilakukan oleh Pace, Silk, Nazione, Fournier dan Collins-Eaglin (2018) mendukung hal tersebut. Hasilnya diketahui bahwa bukan hanya sikap yang menjadi penghalang mahasiswa dalam mencari bantuan psikologis, namun ada empat faktor lain. Faktor pertama yakni kesadaran atau sejauh mana pemahaman mahasiswa terhadap isu kesehatan mental, yang diikuti dengan pengetahuan mengenai sumber daya kesehatan mental yang dimiliki oleh universitas. Faktor kedua yakni stigma. Pace et al. (2018: 2) menyebutkan bahwa mahasiswa yang mendapatkan pandangan negatif terkait isu kesehatan mental yang sedang dialami cenderung tidak akan mencari bantuan atau berbicara mengenai kebutuhan kesehatan mental mereka. Faktor ketiga yakni dukungan teman sebaya. Pace et al. (2018: 2) menyatakan bahwa dukungan sosial dari teman sebaya dapat memfasilitasi pencarian bantuan kesehatan mental. Faktor keempat yakni kampanye yang dilakukan oleh pihak kampus sendiri sebagai upaya mempromosikan kesehatan mental (campus campaign).

Berdasarkan paparan di atas, maka penelitian mengenai sikap mencari bantuan terhadap layanan psikologis perlu dilakukan. Penelitian ini dilakukan di Universitas Al Azhar Indonesia, mengingat kondisi kampus yang berada di wilayah urban yang dinamis dan sarat dengan arus informasi yang pesat. Lokasi perguruan tinggi yang seperti ini menjadi salah satu faktor pendukung akan pentingnya promosi kesehatan mental untuk mahasiswa. Selain itu, Universitas Al Azhar Indonesia telah memiliki unit layanan psikologi khusus mahasiswa.

Fokus studi ini ada pada dua pertanyaan penelitian, pertama, seperti apa sikap mahasiswa dalam mencari bantuan psikologis yang terdapat di Pendidikan tinggi? Kedua, bagaimana kesadaran, 
stigma, teman sebaya, dan kampanye memengaruhi keputusan mahasiswa dalam mencari pertolongan psikologis yang dimiliki oleh perguruan tinggi? Pertanyaan tersebut diteliti menggunakan mixed method, di mana pengumpulan data kuantitatifnya dilakukan dengan menggunakan kuesioner Attitude Toward Seeking Professional Psychological Help, sedangkan data kualitatif diperoleh menggunakan wawancara dengan format semi terbuka via telepon. Pemilihan responden dilakukan dengan menggunakan purposive sampling. Data kuantitatif dikumpulkan dari 180 orang mahasiswa dan dianalisis menggunakan statistik deskriptif. Data kualitatif dikumpulkan dari 12 mahasiswa dan dianalisis menggunakan analisis tematik.

\section{Sikap terhadap Pencarian Bantuan Psikologis}

Konstruk dasar dari sikap dapat ditelusuri melalui teori planned behavior yang dikemukakan oleh Ajzen pada tahun 1991 (Mesidor \& Sly, 2014). Sikap terhadap perilaku didefinisikan sebagai evaluasi individu atas perilaku tertentu, disertai keyakinan bahwa perilaku tersebut akan menuai hasil positif atau negatif. Sikap secara tidak langsung dapat memengaruhi perilaku mencari bantuan melalui intensi, dan merupakan pemantik untuk intensi dan perilaku mencari bantuan yang sebenarnya. Chen, Liu, Wang, Yang, Ruan dan Liu (2020) berpendapat bahwa untuk mempromosikan perilaku mencari bantuan, langkah pertamanya adalah meningkatkan atau mengubah sikap terhadap pencarian bantuan ke arah yang lebih positif.

Sementara itu, pencarian bantuan psikologis (psychological help seeking) didefinisikan oleh Chandrasekara (2016 234) sebagai setiap upaya untuk mencari bantuan terhadap masalah kesehatan mental, baik itu bantuan formal yang diberikan oleh konselor dan psikolog profesional, atau dukungan informal yang diberikan oleh teman dan anggota keluarga. Sementara itu, Oluyinka (2011: 310) memak- nai sikap pencarian bantuan psikologis (attitude towards seeking psychological help) sebagai suatu reaksi evaluatif untuk mencari atau menolak bantuan profesional terhadap ketidaknyamanan psikologis yang dirasakan. Sikap pencarian bantuan psikologis juga dapat dikonseptualisasikan sebagai kesediaan untuk mencari pertolongan profesional ketika mengalami gangguan psikologis.

Studi yang dilakukan Vidourek et al. (2014) menyebutkan bahwa individu dengan sikap negatif terhadap pencarian bantuan psikologis cenderung merasa malu yang akan berujung pada penundaan identifikasi masalah yang dirasakan. Chandrasekara (2016) menyatakan bahwa pada fase remaja, yang mana juga merupakan fase mahasiswa, belum dapat mengidentifikasi masalah psikologis yang masih dalam taraf normal atau sudah berada di ambang batas yang harus segera diberikan pertolongan. Selain itu, individu yang memiliki sikap negatif terhadap pencarian bantuan psikologis cenderung memandang bahwa mencari bantuan profesional sebagai indikator kelemahan dan ketidakmampuan dalam mengatasi masalahnya sendiri.

Dalam konteks penelitian ini, sikap terhadap pencarian bantuan psikologis didefinisikan sebagai penilaian baik positif atau negatif terhadap upaya yang dilakukan individu dalam rangka mencari bantuan pada layanan psikologis yang dimiliki perguruan tinggi untuk menanggulangi ketidaknyamanan psikologis yang dirasakannya. Fischer dan Farina (1995, dalam Oluyinka, 2011) menyatakan bahwa sikap mencari bantuan psikologis sangat terkait dengan perilaku mencari bantuan yang sebenarnya sehingga penting untuk melakukan eksplorasi terhadap sikap mencari bantuan layanan psikologis pada mahasiswa. Pengetahuan tentang hal ini akan membantu para penyedia layanan psikologis untuk dapat memberikan program dan layanan yang menarik bagi individu yang membutuhkan. 
Kesadaran, Stigma, Dukungan

\section{Teman Sebaya, dan Kampanye}

Sikap negatif banyak dilaporkan menjadi penyebab kurangnya perilaku mencari bantuan psikologis (Chandrasekara, 2016; Oluyinka, 2011; Vidourek et al., 2014). Selain sifat negatif, studi yang dilakukan Pace et al. (2018) menemukan bahwa terdapat empat faktor yang memengaruhi keputusan seseorang untuk mencari bantuan ketika dihadapkan dengan permasalahan psikologis.

Faktor pertama, yaitu kesadaran mengenai kesehatan mental dan sumber daya yang bisa digunakan ketika merasakan masalah psikologis. Studi yang dilakukan Eisenberg et al. (2007, dalam Pace et al., 2018: 2) menemukan bahwa kurangnya kesadaran akan layanan psikologis yang tersedia bisa saja menjadi penghalang bagi mahasiswa untuk mencari bantuan mental. Pada konteks penelitian ini, kesadaran merujuk pada pengetahuan mengenai la-yanan psikologis yang tersedia hingga je-nis bantuan apa saja yang ditawarkan pihak kampus. Kurangnya kesadaran akan layanan psikologis ini membuat seseorang sulit untuk aktif mencari bantuan.

Faktor kedua adalah stigma. Pada konteks penelitian ini, stigma didefinisikan sebagai tanggapan negatif yang diberikan oleh lingkungan terkait perilaku mencari bantuan psikologis yang individu lakukan. Individu yang mendapat stigma negatif terkait permasalahan psikologis yang dialami akan cenderung pasif dalam mencari bantuan (Vidourek et al., 2014). Pace et al. (2018) memaparkan stigma umum yang biasa terjadi terkait masalah psikologis, misalnya menganggap individu dengan masalah psikologis adalah individu yang lemah, tidak kompeten, dan tidak berdaya atas diri mereka sendiri. Lebih lanjut, sejauh mana individu menginternalisasi stig-ma dari lingkungan akan memengaruhi harga diri dan identitas mereka. Kondisi ini semakin menjadi penghalang bagi individu untuk mendapatkan penanganan yang tepat.
Faktor ketiga yakni dukungan teman sebaya. Dukungan sosial dari teman sebaya diketahui memiliki pengaruh signifikan dalam menurunkan beban pikiran dan perilaku bunuh diri, dan meningkatkan perilaku mencari bantuan (Repper \& Carter, 2011). Pengaruh yang signifikan dari teman sebaya berasal dari posisi teman sebaya yang unik untuk dapat mengidentifikasi individu dengan gejala gangguan psikologis, karena frekuensi interaksi yang tinggi. Teman sebaya juga dapat memberikan dukungan untuk mencari bantuan konseling. Studi menunjukkan bahwa dua per tiga dari mahasiswa yang memiliki pikiran dan keinginan untuk bunuh diri, memilih teman sebaya sebagai tempat mereka mengungkapkan pikiran dan keinginannya tersebut (Pace et al., 2018). Selain itu, kekuatan dari teman sebaya adalah dengan berbicara mengenai masalah psikologis yang dialami, teman sebaya dapat menormalkan kembali perilaku dan mengurangi persepsi akan stigma yang muncul dari lingkungan (Hirsch \& Barton, 2011).

Faktor keempat yakni kampanye yang dilakukan pihak perguruan tinggi. Kampanye merujuk pada sejauh mana fasilitas psikologis universitas mengangkat topik mengenai pentingnya pertolongan terhadap isu kesehatan mental serta mempromosikan keberadaan dan layanan yang dimilikinya. Kampanye dapat menjadi salah satu jalan untuk mengatasi kurangnya kesadaran akan layanan, pandangan negatif yang muncul dari lingkungan, dan rendahnya dukungan teman sebaya. Studi Champlin dan Nisbett (2018) menunjukkan bahwa dengan kampanye yang efektif akan meningkatkan kesadaran mahasiswanya terkait masalah psikologis di tataran universitas. Kampanye dapat mengatasi hambatan stigma dan mendorong dukungan teman sebaya untuk semakin sadar terkait masalah psikologis.

Universitas Al Azhar Indonesia, (UAl) sebagai universitas yang terletak di wilayah urban yang dinamis, tidak luput dari isu-isu 
terkait kesehatan mental para mahasiswa. Pada tahun 2016, unit Layanan Psikologi di UAI telah mengidentifikasi jenis permasalahan yang paling banyak ditangani di kalangan mahasiswa, yaitu prestasi menurun, kesulitan ekonomi, emosi meledakledak, depresi, menghadapi teman yang menggunakan narkoba, pertikaian dengan teman, tidak punya orientasi karir/masa depan, kurang percaya diri, underachiever, dan malas beribadah. Data permasalahan juga menunjukkan bahwa sivitas akademika butuh mediator yang dapat membantu dalam mengenali potensi diri ketika menghadapi situasi sulit dan mengembangkannya dalam bentuk langkah-langkah konkret yang bertujuan, terarah, dan produktif.

Permasalahan yang dialami mahasiswa ini mendapat perhatian para pimpinan UAI. Terlebih saat pandemi Covid-19 dinyatakan sebagai bencana dunia di awal tahun 2019, para pimpinan menyepakati agar unit layanan konseling mahasiswa segera menyediakan konseling secara daring. Unit layanan konseling ini merupakan fasilitas gratis yang dapat diakses oleh seluruh mahasiswa UAl di mana pun mereka berada. Pemutakhiran unit layanan mahasiswa yang dimiliki UAI ini merupakan implementasi Peraturan Pemerintah Nomor 4 Tahun 2014 tentang Penyelenggaraan Pendidikan Tinggi dan Pengelolaan Perguruan Tinggi.

Berbagai fenomena masalah psikologis yang terjadi di populasi mahasiswa membuat pihak perguruan tinggi selayaknya menyediakan layanan psikologis yang memadai. Namun sayangnya, unit layanan psikologi ini masih belum dimanfaatkan secara optimal dan lebih bersifat kuratif.

Penelitian ini merupakan preliminary research dan dilakukan kepada sampel terbatas, yaitu pada mahasiswa UAI Jakarta. Pertimbangan pemilihan perguruan tinggi ini adalah adanya informasi tentang permasalahan yang dialami mahasiswa dan kekhasan penanganan kesehatan mental yang dilakukan oleh unit layanan bantuan psikologis khusus mahasiswa.
Penelitian ini bertujuan untuk memberikan gambaran seperti apa sikap mahasiswa dalam mencari bantuan psikologis pada perguruan tinggi yang telah memiliki layanan psikologis bagi mahasiswa. Penelitian ini juga memberikan gambaran tentang sudut pandang mahasiswa terhadap kesadaran akan layanan psikologis kampus, stigma yang muncul ketika mereka hendak mencari bantuan melalui layanan psikologis, bentuk dukungan teman sebaya, dan pandangan mahasiswa terhadap kampanye yang selama ini dilakukan oleh unit pelaksana layanan psikologis di kampus. Hasil penelitian ini diharapkan dapat menjadi rujukan layanan kesehatan mental pada remaja, khususnya mahasiswa.

\section{Metodologi Penelitian}

\section{Metode dan Partisipan}

Penelitian ini menggunakan metode campuran (mixed method) dengan teknik pemilihan responden yang menggunakan purposive sampling (Creswell, 2017). Data kuantitatif dikumpulkan dari seratus delapan puluh mahasiswa (30\% laki-laki dan $70 \%$ perempuan) yang berasal dari enam fakultas yang terdapat di UAI. Proses pengumpulan data kuantitatif dilakukan melalui kuesioner yang disajikan menggunakan google form.

Terjaring 180 mahasiswa yang mengisi kuesioner dan berasal dari enam fakultas di UAI, yakni 30 orang mahasiswa berasal dari Fakultas Sains dan Teknologi (16,7\%), 30 orang dari Fakultas Ekonomi dan Bisnis (16,7\%), 30 orang dari Fakultas Hukum $(16,7 \%), 30$ orang dari Fakultas IImu Sosial dan IImu Politik (16,7\%), 30 orang dari Fakultas Psikologi dan Pendidikan (16,7\%), serta 30 orang mahasiswa dari Fakultas IImu Pengetahuan Budaya (16,7\%).

Sementara itu, data kualitatif digali dari dua belas mahasiswa yang mewakili setiap fakultas. Data kualitatif diperoleh menggunakan format wawancara semi terbuka yang dilakukan melalui sambungan telepon dari bulan Agustus sampai Oktober 2020. 


\section{Pengukuran}

Sikap terhadap pencarian bantuan psikologis diukur menggunakan adaptasi kuesioner Attitude Toward Seeking Professional Psychological Help (ATSPPH). ATSPPH merupakan kuesioner versi singkat yang dikembangkan oleh Fischer dan Farina pada tahun 1970. Proses adaptasi bahasa menggunakan panduan dari Beaton, Bombardier, Guillemin, dan Ferraz (2000), yakni tahapan forward translation yang dilakukan oleh tiga orang dosen dan satu orang native. Hasil translasi kemudian masuk ke dalam tahapan sintesis untuk menentukan kedekatan butir pernyataan dengan konteks budaya Indonesia. Proses berikutnya adalah backward translation untuk melihat apakah makna dari hasil translasi tidak jauh berbeda dengan makna kuesioner aslinya.

Setelah proses adaptasi selesai, kemudian dilakukan uji coba terpakai pada 180 responden dan menghasilkan delapan butir pernyataan dengan nilai alpha sebesar 0,597 . Pilihan jawaban berkisar dari skor 1 (sangat tidak setuju) dan skor 4 (sangat setuju). Skor total berkisar dari nol hingga 40, dengan skor yang lebih tinggi menunjukkan sikap positif terhadap pencarian bantuan psikologis.

Setelah mengisi skala sikap, responden kemudian diminta untuk menjawab empat pertanyaan yang peneliti tambahkan terkait layanan psikologis yang dimiliki kampus. Keempat pertanyaan tersebut yaitu: (1) apakah anda pernah melakukan konsultasi di layanan psikologi?; (2) apakah anda mengetahui bahwa UAI memiliki layanan psikologis untuk mahasiswa?; (3) apakah anda pernah mendengar layanan psikologis di UAI?; (4) jika anda membutuhkan layanan psikologis, apakah anda akan mencari layanan psikologis yang tersedia di kampus?

Sementara itu, pengumpulan data deskriptif dijaring melalui wawancara semi terbuka. Format wawancara semi terbuka disusun untuk menggali keempat faktor yang berkontribusi terhadap pencarian bantuan psikologis. Faktor pertama yakni kesadaran mahasiswa mengenai ketersediaan layanan psikologis yang tersedia di universitas (contoh: "apakah anda mengetahui program yang dimiliki oleh unit layanan psikologi mahasiswa?"). Faktor kedua yakni stigma yang didapat dari lingkungan jika mengakses layanan psikologi atau konseling (contoh: "menurut anda, seperti apa respons orang tua, teman, saudara, atau orang lain ketika tahu bahwa anda melakukan konseling?"). Faktor ketiga, dukungan teman sebaya yang digali dengan beberapa pertanyaan seperti "kirakira apa yang akan dikatakan oleh teman anda, kalau mereka tahu bahwa anda mengakses layanan psikologis?", atau "bagaimana respons teman anda jika anda bercerita kepadanya bahwa anda memiliki permasalahan mental?". Faktor terakhir yang digali adalah sudut pandang mahasiswa terhadap kampanye yang dilakukan oleh pihak universitas dalam rangka mempromosikan layanan psikologis yang dimilikinya.

\section{Analisis Data}

Analisis data kuantitatif dilakukan dengan menggunakan statistik deskriptif melalui skor rata-rata untuk menentukan kategorisasi skor sikap terhadap pencarian bantuan psikologis. Sementara itu, data hasil wawancara dengan kedua belas responden turut dianalisis dengan menggunakan analisis tematik, yang mencakup pencatatan hasil wawancara, membuat outline, melakukan perbandingan dan pengelompokkan outline, menyusun tema dan coding, dan membangun evaluasi. Terakhir, data deskriptif diinterpretasi dan ditarik kesimpulan. Adapun tahapan analisis tematik yang akan dilakukan lebih jelasnya digambarkan melalui Bagan 1.

\section{Tahapan Penelitian}

Alur penelitian ini dimulai dengan menelusuri data mahasiswa untuk kemudian menentukan sampling. Terdapat enam fakultas di Universitas Al Azhar Indonesia. 


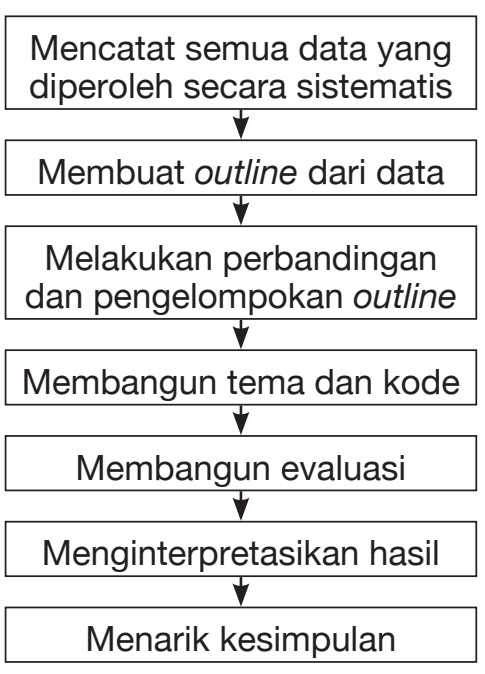

Bagan 1.

Tahapan Analisis Tematik

Dari tiap fakultas diambil sampel sebanyak 30 orang mahasiswa aktif. Setelah sampling ditentukan, maka selanjutnya adalah pengisian kuesioner mengenai sikap. Setelah kuesioner sikap terisi, proses selanjutnya mengisi survei yang berisi lima pertanyaan. Selanjutnya adalah melakukan wawancara kepada 12 orang mahasiswa untuk mendapatkan data deskriptif mengenai persepsi mahasiswa mengenai kesadaran, stigma, dukungan teman sebaya, dan kampanye, terhadap layanan psikologis yang dimiliki perguruan tinggi, dalam hal ini adalah unit layanan psikologi. Hasil penelitian ini diharapkan dapat menjadi rekomendasi bagi pihak universitas, pusat konseling universitas, dosen pembimbing akademik, dan juga kebijakan di tingkat nasional mengenai standar pelayanan Kesehatan mental mahasiswa.

\section{Hasil dan Pembahasan}

Hasil pengolahan data dengan menggunakan bantuan SPSS 24 diperoleh skor dengan rentang 22 sampai $36(\mathrm{M}=28$. $\mathrm{SD}=2,6$ ). Dari perolehan skor tersebut, maka dibuat tiga kategori sikap terhadap pencarian bantuan psikologis yang merujuk pada Chen et al. (2020). Kategori rendah mengindikasikan mahasiswa memiliki sikap cenderung negatif. Kate- gori sedang mengindikasikan mahasiswa memiliki sikap netral (neutral attitude) terhadap pencarian bantuan psikologis. Kategori tinggi mengindikasikan mahasiswa memiliki sikap positif terhadap pencarian bantuan psikologis. Ketiga kategorisasi sikap mahasiswa terhadap pencarian bantuan dirangkum melalui Tabel 1 berikut.

Tabel 1.

Gambaran Sikap terhadap

Pencarian Bantuan Psikologis Mahasiswa

\begin{tabular}{lcc}
\hline \multicolumn{1}{c}{ Kategori } & Sampel (n) & Persentase (\%) \\
\hline Rendah & 24 & 13,3 \\
Sedang & 108 & 60,0 \\
Tinggi & 48 & 26,7 \\
\hline Total & 180 & 100,0 \\
\hline
\end{tabular}

Dari Tabel 1 di atas dapat diketahui bahwa sebesar $60 \%$ mahasiswa $(n=108)$ berada dalam kategori sedang. Hal ini dapat diartikan bahwa mahasiswa belum sepenuhnya memiliki kesadaran mengenai pentingnya bantuan profesional terhadap isu atau masalah psikologis yang dihadapinya. Hanya sebesar $26,7 \%$ mahasiswa (n = 48) yang memiliki sikap positif tentang pencarian bantuan psikologis. Pencarian bantuan dalam kategori tinggi, dapat kita katakan bahwa mereka sudah memiliki sikap yang positif terhadap pentingnya bantuan profesional dan memiliki kesadaran yang baik mengenai isu atau masalah psikologis yang dihadapi. Sisanya, sebesar $13,3 \%$ mahasiswa $(n=24)$ berada dalam kategori rendah atau sikap negatif terhadap pencarian bantuan psikologis. Meskipun persentasenya kecil dibanding dua kategori sebelumnya, angka ini layak mendapat perhatian dari pihak universitas dan penyedia layanan psikologis. Sikap negatif mengindikasikan masih kurangnya kesadaran terhadap permasalahan mental, masih menganggap bahwa isu psikologis akan selesai dengan sendirinya, memiliki gagasan bahwa membicarakan masalah pribadi adalah hal yang buruk, serta mendapat bantuan profesional ditempatkan sebagai pilihan terakhir. 
Selanjutnya, dari 180 responden menjawab pertanyaan pertama yakni apakah anda pernah melakukan konsultasi psikologis. Hasil menunjukkan bahwa sebesar 88,9\% mahasiswa $(n=160)$ belum pernah memiliki pengalaman terlibat dengan layanan psikologis, baik itu konsultasi kepada psikolog dan konselor. Hanya $11,1 \%$ mahasiswa $(n=20)$ yang memiliki pengalaman pernah terlibat dalam konsultasi psikologis. Dari persentase mahasiswa yang pernah konsultasi, $17 \mathrm{di}$ antaranya berjenis kelamin perempuan, dan 3 orang sisanya berjenis kelamin lakilaki.

Pertanyaan kedua yakni apakah anda mengetahui bahwa UAI memiliki layanan psikologis untuk mahasiswa. Dari 180 res-ponden, 62,2\% ( $\mathrm{n}=112)$ menyatakan tidak tahu. Sisanya sebesar 37,8\% $(n=68)$ menyatakan tahu. Mayoritas sumber informasi yang responden dapatkan tentang ketersediaan layanan psikologis di UAI bersumber dari Instagram UAI, student desk, informasi ketika masa Pengenalan Kehidupan Kampus Mahasiswa Baru (PKKMB), informasi dari dosen dan dari broadcast message di platform sosial media.

Berikutnya pertanyaan ketiga yaitu apakah anda pernah mendengar layanan psikologis dari unit layanan psikologi mahasiswa. Dari 180 respons yang masuk, 26,1\% ( $n=47)$ mahasiswa menyatakan pernah mendengar tentang unit layanan psikologi untuk mahasiswa. Sisanya sebanyak 73,9\% ( $n=133)$ menyatakan belum pernah mendengar bahwa ada layanan psikologis yang dapat diakses untuk mahasiswa. Sumber informasi mengenai unit layanan psikologi untuk mahasiswa cenderung beragam. Responden menyatakan mengetahui unit layanan psikologi untuk mahasiswa dari broadcast group, dijelaskan ketika awal masuk perkuliahan, khususnya saat sesi sosialisasi unit layanan mahasiswa yang tersedia di kampus, dan mendapatkan informasinya dari dosen maupun teman.
Pertanyaan keempat yaitu jika anda membutuhkan layanan psikologis, apakah anda akan mencari layanan psikologis yang ada di UAI? Dari 180 respons yang masuk, $88,9 \%(n=160)$ menyatakan Ya, akan menggunakan layanan psikologis yang ada di UAl. Sementara 11,1\% (n = 20) sisanya menyatakan lebih memilih untuk mencari bantuan di luar UAI.

Sementara itu, penggalian data terhadap 12 responden memberikan temuan yang menarik. Terkait aspek pertama yaitu kesadaran mengenai keberadaan layanan bantuan psikologis di kampus, seluruh responden menyatakan tahu keberadaan unit layanan psikologi untuk mahasiswa. Namun, hanya satu orang yang pernah mengakses layanan konseling. Kedua belas responden pun menyatakan tidak me-ngetahui program-program apa saja yang tersedia untuk diakses mahasiswa. Dari segi kesadaran, dapat diketahui bahwa hampir seluruh responden belum pernah menggunakan fasilitas bantuan psikologis. Hanya ada satu responden yang pernah memiliki pengalaman untuk menggunakan layanan psikologis untuk mahasiswa. Itu pun hasilnya tidak begitu menggembirakan karena menurut responden, dirinya kurang ditanggapi dengan baik. Pelayanan yang diberikan tidak mendukung dirinya untuk keluar dari masalah.

Terkait aspek kedua yakni stigma. Hasil wawancara terbuka terhadap 12 res-ponden menemukan bahwa masih ada kekhawatiran. Satu orang responden menyatakan bahwa "malu kalau ketahuan ke psikolog sama orang lain" dan ketakutan jika hal tersebut akan menyebar dan menjadi bahan obrolan bagi orang lain.

Aspek ketiga yakni mengenai dukungan teman sebaya. Hasil wawancara menemukan bahwa 11 responden menyatakan optimis bahwa teman sebaya mereka akan mendukung ketika memutuskan untuk mencari bantuan psikologis. Sementara satu orang menyatakan tidak peduli terhadap opini teman. Dari aspek dukungan 
teman sebaya dapat diketahui bahwa reponden merasa dukungan teman akan semakin menguatkan responden ketika responden memerlukan bantuan ahli. Reponden juga menyatakan bahwa temantemannya akan memberikan kata-kata yang positif dan tidak akan membicarakan di belakang mengenai keputusan untuk mencari bantuan. Teman juga dinyatakan se-bagai orang pertama yang responden pilih ketika berada dalam masalah.

Selanjutnya, peneliti mencoba menggali kampanye yang dilakukan baik oleh pihak universitas maupun penyedia layanan psikologis. Terkait kampanye mengenai isu kesehatan mental di tataran kampus, seluruh responden menyatakan bahwa kampus kurang mengangkat isu-isu penting seperti menjaga kesehatan mental. Salah seorang responden menyatakan "pentingnya mental health begitu mungkin anak psikologi ya yang lebih tahu..", sehingga pentingnya menjaga kesehatan mental masih menjadi topik eksklusif di beberapa program studi saja.

Keseluruhan responden juga pada saat wawancara menyatakan hal yang senada, bahwa responden merasa masih minim mendapatkan informasi terkait layanan psikologis, terutama mengenai hal-hal teknis seperti dengan siapa responden akan berhadapan, berapa durasi waktu yang dibutuhkan untuk sesi konseling, apakah berbayar atau tidak, sampai apakah pihak yang menanganinya akan menjaga privasi responden atau tidak. Setengah responden menyatakan bahwa mereka mengetahui keberadaan unit layanan psikologi untuk mahasiswa melalui instagram kampus, tetapi tidak benar-benar mengetahui program atau layanan apa saja yang ditawarkan. Responden menyatakan "harusnya dibuat semacam frequently asked question (FAQ), jadi kita tidak bingung..", sehingga informasi mengenai ketersediaan layanan psikologis di kampus idealnya diikuti juga dengan pemberian informasi yang bersifat lebih teknis. Responden juga berharap keberadaan layanan psikologis ini bisa diinformasikan terus menerus agar temanteman yang lain bisa mengetahui dan memanfaatkan kesempatan tersebut.

Berdasarkan hasil analisis data mengenai profil sikap mahasiswa terhadap mencari bantuan layanan psikologis serta hasil analisis tematik terhadap wawancara terbuka, dapat ditarik suatu benang merah bahwa sikap mahasiswa terhadap pencarian bantuan layanan psikologis di kampus tergolong masih netral. Hal ini perlu mendapat perhatian penyedia layanan psikologis karena sikap netral jika tidak diberi pemaparan yang tepat, akan berubah menjadi sikap apatis atau ketidakpedulian, bahkan kurangnya minat terkait pencarian bantuan psikologis yang melibatkan pihak profesional. Kelompok mahasiswa dengan sikap netral dan sikap negatif ini idealnya menjadi sasaran intervensi agar mahasiswa ke depannya memiliki sikap yang cenderung mengarah ke positif. hal ini menjadi tugas penyelenggara layanan psikologis di universitas untuk menggiring dan membangun kesadaran mahasiswa bahwa mencari pertolongan terkait masalah mental itu hal yang normal, masalah psikologis belum tentu mampu diselesaikan sendiri, serta anggapan bahwa membicarakan hal pribadi adalah hal yang wajar dalam rangka mencari bantuan.

Selain itu, ditemukan bahwa masih banyak mahasiswa yang belum mengetahui fasilitas layanan bantuan psikologis yang bisa mereka akses. Hal ini menunjukkan bahwa kampanye yang sudah dilakukan melalui sosial media, student desk, PKKMB, sebaran informasi melalui dosen dan mahasiswa, perlu dievaluasi kembali untuk mengetahui dampak kampanye langsung maupun yang tidak langsung terhadap awareness mahasiswa akan ketersediaan akses dan fasilitas layanan bantuan psikologis.

Dari analisis tematik juga didapatkan bahwa merasa didukung oleh teman sebaya jika memutuskan meminta bantu- 
an pada profesional. Menariknya, setengah dari responden menyatakan lebih memilih layanan psikologis di luar kampus, karena merasa takut dibocorkan dan terlalu dekat dengan lingkungan dan aktivitas sehariharinya. Hal ini mengindikasikan responden merasa belum percaya terhadap layanan bantuan psikologis yang dimiliki kampus.

Membangun kesadaran akan pentingnya mencari pertolongan terhadap isu kesehatan mental memang menjadi agenda utama penyedia layanan psikologis di kampus, yang tentunya akan semakin optimal jika pihak pengambil keputusan di perguruan tinggi ikut mengkampanyekan hal yang sama. Intervensi yang dapat dilakukan oleh pihak universitas dalam rangka meningkatkan sikap mahasiswa ke arah yang lebih positif terhadap layanan psikologis adalah dengan menerapkan layanan Dukungan Kesehatan Jiwa dan Psikososial (DKJPS) yang komprehensif dan terinteg-rasi tata kelolanya. Pengembangan bentuk intervensi yang dapat digunakan oleh para stakeholder di perguruan tinggi dapat mengacu kepada piramida intervensi berikut ini.

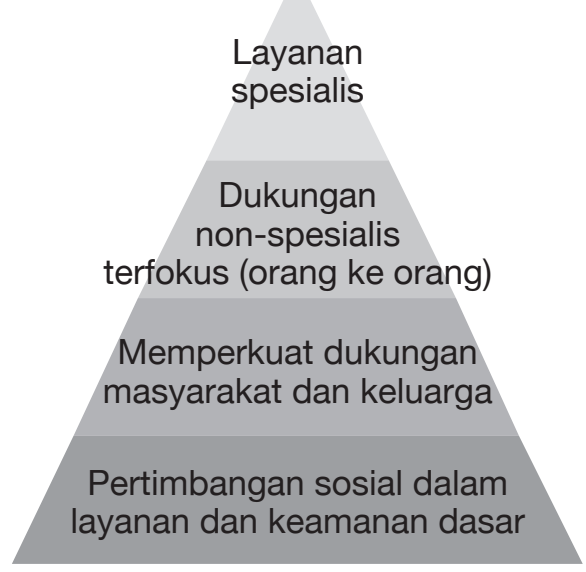

Bagan 2.
Piramida Intervensi Layanan Dukungan $\mathrm{Kes}$

Sumber: Kementerian Kesehatan Republik Indonesia (2020)

\section{Contoh:} masyarakat dan melindungi harga diri.

\section{Kesehatan Jiwa dan Psikososial}

Layanan kesehatan jiwa oleh spesialis kesehatan jiwa (perawat kesehatan jiwa, psikolog, psikiater, dll.).

Layanan kesehatan jiwa dasar oleh dokter layanan primer. Dukungan emosional dan praktis dasar dari kader kesehatan.

Mengaktivasi hubungan sosial, ruang ramah anak yang mendukung. Dukungan tradisional dari masyarakat.

Advokasi layanan dasar yang aman, dapat diterima di

Piramida intervensi di atas sangat representatif dalam mengintegrasikan berbagai pendekatan yang disesuaikan dengan spektrum kebutuhan kesehatan jiwa dan psikososial dan sumber dukungannya (mulai dari tingkat masyarakat/keluarga hingga tenaga ahli). Berdasarkan piramida tersebut, bentuk layanan psikologis yang diberikan dapat dilakukan secara kelompok (keluarga/teman sebaya) maupun individual oleh dosen pembimbing akademis ataupun pelaksana layanan psikologis (psikolog dan konselor).

Di sisi lain, keberadaan unit layanan psikologi dan pelibatan tenaga ahli konselor dalam proses bimbingan perguruan tinggi sudah sesuai dengan Permendiknas Nomor 27 tahun 2008 tentang Stan- dar Kualifikasi Akademik dan Kompetensi Konselor. Namun sayangnya, pemerintah belum menyediakan acuan dalam bentuk Norma, Standar, Prosedur, dan Kriteria (NSPK) mengenai layanan psikologis yang komprehensif dan terintegrasi dengan sumber-sumber dukungan yang dimiliki perguruan tinggi, seperti pusat karir mahasiswa dan unit pengembangan minat, bakat, dan keahlian mahasiswa. Ketiadaan NSPK ini menyebabkan adanya beberapa kondisi berikut.

Pertama, belum adanya program layanan yang tersusun secara sistemik dan berkelanjutan, mulai dari program harian hingga tahunan, khususnya untuk para mahasiswa. Dengan demikian, hendaknya unit penyelenggara layanan psikolo- 
gis di perguruan tinggi memiliki program bantuan psikologis bagi mahasiswa yang lebih komprehensif dan tersusun secara sistemik.

Kedua, layanan psikologis yang dilakukan sifatnya masih terkotak-kotak, misalnya pada dosen pembimbing akademik maupun unit layanan konseling. Selain itu, masih terdapat pula pusat karir mahasiswa dan unit pengembangan pengembangan minat, bakat, dan keahlian mahasiswa yang fungsinya mendukung salah satu layanan bimbingan dan konseling di perguruan tinggi. Sebetulnya, terdapat banyak pihak yang dapat memberikan layanan psikologis di suatu perguruan tinggi, namun belum bersinergi dengan fungsi bimbingan dosen pembimbing akademik dan organisasi mahasiswa yang menjadi motor penggerak dukungan teman sebaya. Belum bersinerginya layanan-layanan tersebut akan menyebabkan pemanfaatan akses belum optimal, yang berdampak kepada kualitas kesejahteraan psikologis mahasiswa.

Ketiga, dosen pembimbing akademik (PA) belum mendapatkan pelatihan untuk meningkatkan pengetahuan dan keterampilan dalam memberikan dukungan psikologis. Misalnya, diberikan pelatihan dukungan psikologis awal (DPA) untuk meningkatkan kepercayaan terhadap dosen sebagai pemberi dukungan psikologis, seperti yang sudah digalakkan di guruguru tingkat satuan pendidikan dasar dan menengah. Adanya peran dosen pembimbing dapat mendorong teman sebaya untuk berpartisipasi aktif dan membantu pembentukan sikap mahasiswa yang lebih positif terhadap kesadaran mengenai kesejahteraan psikologisnya.

Keempat, mahasiswa melalui organisasi kemahasiswaan dan orangtua hendaknya dilibatkan sebagai personil pelaksana dukungan psikologis, sebagai pendukung ketahanan perguruan tinggi. Hal ini juga akan mendukung kampanye kampus untuk meningkatkan kesadaran terhadap isu-isu kesehatan mental. Idealnya ada kebijakan pendukung dari pimpinan perguruan tinggi sebagai payung teknis pelaksanaan, tata kelola, dan sistem rujukan layanan psikologis yang terintegrasi dengan fungsi bimbingan dan konseling di perguruan tinggi. Keberadaan layanan psikologis di perguruan tinggi memiliki andil dalam keberhasilan mahasiswa menyelesaikan studi secara optimal dan tepat waktu. Oleh karena itu, pemerintah hendaknya perlu membuat NSPK terkait untuk mengurangi angka putus kuliah dan demi tercapainya lulusan mahasiswa yang berkualitas seperti yang tercantum dalam Undang-Undang Nomor 20 Tahun 2003 tentang Sistem Pendidikan Nasional.

\section{Penutup}

Sikap mahasiswa terhadap pencarian bantuan psikologis tergolong netral. Hal ini sepatutnya menjadi catatan bagi pihak perguruan tinggi maupun unit penyedia layanan psikologis untuk dapat mengarahkan sikap mahasiswa ke arah yang lebih positif. Selain itu, masih ditemukan stigma negatif terhadap upaya pencarian bantuan. Temuan ini mengindikasikan bahwa masalah psikologis dinilai sebagai sesuatu yang harus diselesaikan sendiri tanpa intervensi orang lain, atau sesuatu yang akan selesai dengan sendirinya. Selebihnya, mahasiswa merasa didukung oleh teman sebayanya jika suatu saat melakukan bantuan psikologis, yang berarti bahwa dukungan teman sebaya yang didapatkan positif dan perlu dipertimbangkan sebagai sumber dukungan psikologis awal yang potensial.

Sementara itu, hasil penelitian ini menunjukkan dengan jelas bahwa kampanye yang dilakukan unit layanan bantuan psikologi di tingkat perguruan tinggi masih perlu dievaluasi kembali. Hal ini ditandai dari masih banyaknya mahasiswa yang belum mengetahui keberadaan unit layanan psikologi yang memberikan layanan psikologis gratis untuk mahasiswa. Belum adanya panduan teknis atau SOP pelaksanaan layanan psikologis yang terinteg- 
rasi dengan pihak-pihak yang dapat memberikan dukungan psikologis kepada mahasiswa di tingkat universitas dapat memperbesar kemungkinan adanya pengalaman yang kurang menyenangkan dalam mengakses layanan psikologis yang tersedia sehingga mahasiswa lebih memilih layanan psikologis dari luar universitas meskipun berbayar. Hal ini juga berkaitan dengan tingkat kepercayaan mahasiswa terhadap pihak pelaksana layanan psikologis. Komitmen pelaksana untuk menjaga kerahasiaan mahasiswa sebagai klien perlu dipahami dan dipatuhi bersama. Kepercayaan dapat terbangun melalui pengalaman positif mahasiswa dalam mengakses layanan psikologis, karena pengalaman ini berfungsi sebagai dukungan yang signifikan kepada mahasiswa lain untuk terus memanfaatkan layanan yang ada atau mengundang ketertarikan mahasiswa yang belum pernah untuk memanfaatkannya.

Berdasarkan hasil penelitian ini, diketahui bahwa upaya penanggulangan isuisu terkait kesehatan mental, khususnya di pendidikan tinggi, akan lebih mudah diterapkan jika beranjak dari pola individu mencari bantuan psikologis. Selain itu, dengan pemerolehan gambaran profil sikap mencari bantuan yang ditemukan pada penelitian ini, dapat disimpulkan bahwa keberadaan unit layanan psikologis perlu didukung dengan kampanye, untuk terus mempromosikan layanan psikologis dan manfaatnya bagi mahasiswa, baik secara akademik maupun nonakademik.

Oleh karenanya, berdasarkan preliminary study ini diharapkan tidak hanya menjadi rujukan layanan psikologis bagi mahasiswa, namun dapat ditindaklanjuti juga menjadi penelitian lanjutan dengan sampel yang lebih luas, yang dapat mendorong terbitnya kebijakan teknis di perguruan tinggi, dengan mengacu kepada Peraturan Pemerintah Nomor 4 Tahun 2014 tentang Penyelenggaraan Pendidikan Tinggi dan Pengelolaan Perguruan Tinggi. Kebijakan ini diharapkan dapat mengintegrasikan layanan psikologis yang dilakukan oleh beberapa pihak, seperti pembimbing akademik, unit layanan pengembangan minat dan bakat mahasiswa (seperti pusat karir dan unit kegiatan mahasiswa), dan unit layanan psikologis yang dimiliki oleh perguruan tinggi.

Terakhir, demi tercapainya mahasiswa yang sehat fisik dan mental, maka hasil penelitian ini menyarankan beberapa hal. Pertama, amanat Undang-Undang Nomor 18 tahun 2014 tentang Kesehatan Jiwa hendaknya dibuatkan peraturan turunan pada tingkat penyelenggaraan universitas melalui peraturan menteri yang menangani pendidikan tinggi. Dalam peraturan menteri tersebut hendaknya mengamanatkan agar universitas menyusun strategi penyelenggaraan unit layanan psikologis remaja yang berkesinambungan, implementatif, komprehensif, dan terintegrasi dengan sumber-sumber dukungan yang dimiliki oleh perguruan tinggi. Kedua, Komisi $X$ DPR RI yang memiliki lingkup tugas pendidikan, olahraga, dan pariwisata, sebaiknya mengawal proses pembentukan aturan turunan tersebut dan mengawasi pelaksanaannya sehingga mahasiswa dapat berperan sebagai sumber daya manusia yang berkualitas, baik fisik maupun mental.

\section{Acknowledgment}

Penelitian ini dapat dilaksanakan atas dukungan dana dari Universitas Al Azhar Indonesia (UAI). Kami mengucapkan terima kasih kepada rekan-rekan di Lembaga Penelitian dan Pengabdian Masyarakat UAl yang telah membantu kami dengan menyediakan hibah untuk penelitian dan publikasi. Kami juga berterima kasih kepada para reviewer atas wawasan dan keahlian yang meningkatkan kualitas penelitian ini. 


\section{Daftar Pustaka}

Al-Darmaki, F. (2011). Needs, attitudes towards seeking professional help, and preferred sources of help among Emirati college students. Journal for International Counselor Education, 3, 39-57. Diakses dari http://digitalcommons.library.unlv. edu/jice

Beaton, D. E., Bombardier, C., Guillemin, F., \& Ferraz, M. B. (2000). Guidelines for the process of cross-cultural adaptation of self-report measures. Spine, 25(24), 31863191. doi: 10.1097/00007632-20001215000014

Champlin, S., \& Nisbett, G. (2018). Promoting mental health resource use on campus by "trying something new". American Journal of Health Promotion, 32(4), 1140-1144. doi: 10.1177/0890117117740348

Chandrasekara, S. (2016). Help-seeking attitudes and willingness to seek psychological help: application of the theory of planned behavior. International Journal of Management, Accounting, and Economics, 3(4), 233-245

Chen, P., Liu, X. J., Wang, X. Q., Yang, B. X., Ruan, J., \& Liu, Z. (2020). Attitude toward seeking professional psychological help among community-dwelling population in China. Frontiers in psychiatry, 11, 417. doi: 10.3389/fpsyt.2020.00417

Creswell, J. W. (2017). Research design: qualitative, quantitative, and mix method. New York: SAGE Publication.

Danzman, R. (2019, Agustus 21). Counseling and psychological services for college students. [Blog post]. Diakses dari https:// www.psychologytoday.com/us/blog/ campus-crunch/201908/counseling-andpsychological-services-college-students

Fisher, M. B., \& Noble, J. L. (1960). Me, myself, and I: Self-discovery and selfdevelopment. Dalam M. B. Fisher, \& J. L. Noble, Prentice-Hall psychology series. College education as personal development, hal. 3-24. Prentice-Hall, Inc. doi: 10.1037/14330-001
Griffiths, K. M., Crisp, D. A., Barney, L., \& Reid, R. (2011). Seeking help for depression from family and friends: a qualitative analysis of perceived advantages and disadvantages. BMC Psychiatry, 11, 196. doi: 10.1186/1471-244X-11-196

Hirsch, J., \& Barton, A. (2011). Positive social support, negative social exchanges, and suicidal behavior in college students. Journal of American College Health, 59, 393-8. doi: $10.1080 / 07448481.2010 .515635$

Ikatan Lembaga Mahasiswa Psikologi Indonesia. (2020). Layanan kesehatan mental di lingkungan kampus: urgensi dan solusi [Artikel Kajian]. Diakses dari http:// ilmpi.org/artikel-kajian/artikel/layanankesehatan-mental-di-lingkungan-kampusurgensi-dan-solusi/

Kementerian Kesehatan Republik Indonesia. (2018). Hasil Utama Riskesdas 2018. Diakses dari https://www.litbang.kemkes. go.id/hasil-utama-riskesdas-2018/

Kementerian Kesehatan Republik Indonesia. (2020). Pedoman Dukungan Kesehatan Jiwa dan Psikososial Pada pandemi Covid-19. Jakarta: Direktorat Pencegahan dan Pengendalian Masalah Kesehatan Jiwa dan Napza, Direktorat Jenderal Pencegahan dan Pengendalian Penyakit, Kementerian Kesehatan RI.

Kementerian Pendidikan Nasional RI. (2008). Peraturan Mendiknas tentang tentang Standar Kualifikasi Akademik dan Kompetensi Konselor (Permendiknas Nomor 27 Tahun 2008). Diakses dari https://bsnp-indonesia.org/id/wp-content/ uploads/tenaga/Permen_27_Th-2008.pdf

Krishnan, L., \& Sequeira, A. H. (2012). Stress among college students and how to combat it. SSRN Electronic Journal. doi: 10.2139/ssrn.2041423

Mesidor, J. K., \& Sly, K. F. (2014). Mental health help-seeking intentions among international and african american college students: an application of the theory of planned behavior. Journal of International Students, 4(2), 137-149. doi: 10.32674/jis. v4i2.474 
Oluyinka, O. (2011). Psychological predictors of attitude towards seeking professional psychological help in a Nigerian university student population. South African Journal of Psychology, 41(3), 310-327. doi: 10.1177/008124631104100306

Pace, K., Silk, K., Nazione, S., Fournier, L., \& Collins-Eaglin, J. (2018). Promoting mental health help-seeking behavior among first-year college students. Health Communication, 33(2), 102-110. https:// doi: 10.1080/10410236.2016.1250065

Pedrelli, P., Nyer, M., Yeung, A., Zulauf, C., \& Wilens, T. (2015). College students: mental health problems and Treatment Considerations. Academic psychiatry, 39(5), 503-511.

Peraturan Pemerintah tentang Penyelenggaraan Pendidikan Tinggi dan Pengelolaan Perguruan Tinggi (2014).

Rasyida, A. (2019). Faktor yang menjadi hambatan untuk mencari bantuan psikologis formal di kalangan mahasiswa. Persona: Jurnal Psikologi Indonesia, 8(2), 193-207. doi: 10.30996/persona.v8i2.2586

Repper, J., \& Carter, T. (2011). A review of the literature on peer support in mental health services. Journal of mental health (Abingdon, England), 20(4), 392-411. doi: 10.3109/09638237.2011.583947

Undang-Undang tentang Kesehatan Jiwa (2014).

Vidourek, R. A., King, K. A., Nabors, L. A., \& Merianos, A. L. (2014). Students' benefits and barriers to mental health help-seeking. Health Psychology and Behavioral Medicine: an Open Access Journal, 2(1), 1009-1022. doi: 10.1080/21642850.2014.963586

World Health Organization. (2020). Guidelines on mental health promotive and preventive interventions for adolescents: helping adolescents thrive. Geneva: World Health Organization. Diakses dari https://www. who.int/publications/i/item/guidelines-onmental-health-promotive-and-preventiveinterventions-for-adolescents 